\title{
Relationship Between Mother's Knowledge Of Breast Milk Companion Food With Accuracy of Breastfeeding Companion Feeding
}

\author{
Ayu Andhira ${ }^{1}$, Tenriwati ${ }^{2}$, Haerati $^{3}$ \\ ${ }^{1}$ Nursing Student, Stikes Panrita Husada Bulukumba, Indonesia \\ ${ }^{2,3}$ Departement of Nursing, Stikes Panrita Husada Bulukumba, Indonesia
}

*Corresponding author: Tenriwati

Email: tenriwatisalala@gmail.com

\begin{abstract}
ABSTRAC
Background: Breast milk companion food should be given after the baby is 6 months old because it can provide great benefits to the baby (Alam, 2010). Factors that play an important role to prevent improper feeding of breast milk are maternal knowledge factors and maternal work factors. Maternal behavior in this case plays an important role to prevent improper feeding of breast milk so that it will reduce the risk of the baby experiencing indigestion and can have stronger endurance. There are some mothers who provide breast milk companion food is not on time. Research objectives: To Find Out the Relationship Between Maternal Knowledge Levels About Breast Milk Companion Foods With Timeliness of Breastfeeding Companion Feeding in the Working Area of Puskesmas Caile Bulukumba Regency. Method: This type of research is quantitative research using non-experimental design using the Cross Sectional approach. A sample of 49 respondents was taken by the consecutive sampling method. The data analysis in this study used a chi-square test statistical test. Results: Based on the results of univariate analysis, it is known that the mother's knowledge of MP-BREAST MILK feeding is at most sufficient and good categories as many as 44 people (67.7\%). And the timeliness of giving MP-BREAST MILK is the most appropriate category as many as 38 people (58.5\%). The results of the analysis using the chi-suare test obtained a significancy value of $0.001(\mathrm{p}<0.05)$. Conclusion: There is a relationship between the level of maternal knowledge about breast milk companion food and the timeliness of breastfeeding companion feeding in the working area of the puskesmas caile bulukumba district. And it is recommended for hospital institutions are expected to consider applying as a nursing relationship between the level of maternal knowledge about breast milk companion food with the timeliness of breastfeeding companion feeding
\end{abstract}

Keyword: maternal knowledge about MP-BREAST MILK. timeliness of mp-breast milk 


\section{PENDAHULUAN}

World Health Organization (WHO) 2015 menyatakan bahwa hanya 63\% bayi di dunia yang mendapatkan ASI eksklusif sedangkan 37\% bayi lainnya ternyata telah mendapatkan MPASI saat usianya < dari 6 bulan. Hal ini menggambarkan bahwa praktek pemberian MPASI dini diberbagai negara masih cukup tinggi. World Health Organization (WHO) juga mempersentasekan nahwa sekitar 32\% anak usia balita di negara-negara berkembang menderita stunting dan 10\% wasting disebabkan oleh MP-ASI yang tidak optimal.

Data Survei Demografi Kesehatan Indonesia (SDKI) yang diperoleh dari Pusat Data dan Informasi (Pusdatin) Kementerian Kesehatan RI tentang cakupan cakupan pemberian makanan pendamping ASI (MP-ASI) bagi bayi usia 0-6 bulan di Indonesia dalam kurung waktu tiga tahun terakhir yakni pada tahun 2017 cakupan bayi mendapat MP-ASI sebesar 61,33\%. Pada tahun 2018 capaian cakupan bayi mendapat MP-ASI sebesar 65,16\%. Sementara itu pada tahun 2019 cakupan bayi mendapat MP-ASI sebesar 68,74\%. Hal ini menggambarkan bahwa praktek pemberian MP-ASI secara nasional masih cukup tinggi dan telah melampaui target renstra tahun 2019 sebesar 46\%. Namun demikian masih ada sebanyak 6 (enam) provinsi yang belum mencapai target rentra tahun 2019 (Permatasari, 2019).

Sementara data demografi kesehatan provinsi Sulawesi Selatan tentang cakupan pemberian makanan pendamping ASI (MP-ASI) di tiga tahun terakhir yakni pada tahun 2017 cakupan pemberian makanan pendamping ASI (MP-ASI) sebesar 80,46\%, dan pada tahun 2018 mengalami penurunan renstra ke 73,56\%. Sementara pada tahun 2019 cakupan pemberian makanan pendamping ASI (MP-ASI) kembali meningkat dan mencapai angka 81,33\%. Pemberian makanan pendamping ASI pada 13.820 balita yang tersebar di 24 Kabupaten/kota, terdapat 5 (lima) Kabupaten/kota dengan capaian proporsi tertinggi cakupan pemberian MP-ASI yakni Kabupaten Sinjai, Bantaeng, Takalar, Sindrap dan Maros dengan persentase rata-rata mencapai $44 \%$, data ini lebih tinggi dibandingkan target renstra provinsi secara nasional yakni 34,5\%. Hal ini menggambarkan bahwa kecenderungan masyarakat Sulawesi Selatan mengetahui dan memahami pentingnya pemberian makanan pendampin ASI untuk kesehatan dan tumbuh kembang bayi (Dinkes Sul-Sel, 2019). Kejadian permasalahan pemberian makanan pendamping ASI pada anak umumnya disebabkan karena minimnya pengetahuan ibu tentang pentingnya pemberian makanan pendamping ASI, hal ini juga ditemukan menurut hasil wawancara pada saat pengambilan data awal di puskesmas Caile kabupaten Bulukumba dengan ibu yang memiliki bayi usia 0-12 bulan. Dari hasil observasi 
dari 5 jumlah responden ibu terdapat 2 responden yang memberikan makanan pendamping ASI sebelum anak beusia 6 bulan.

Berdasarkan gambaran fenomena di atas, sehingga melatarbelakangi penulis melakukan penelitian dengan judul, Hubungan Antara Pengetahuan Ibu Tentang Makanan Pendamping ASI dengan Ketepatan Pemberian Makanan Pendamping ASI di Puskesmas Caile Kabupaten Bulukumba.

\section{METODE PENELITIAN}

\section{Desain Penelitian}

Desain penelitian merupakan rencana penelitian yang disusun sedemikian rupa sehingga peneliti dapat memperoleh jawaban yang sesuai terhadap pertanyaan penelitian. Jenis penelitian ini adalah jenis penelitian kuantitatif. Jenis penelitian ini menggunakan rancangan penelitian deskriktif karena penelitian ini bertujuan untuk mengetahui hubungan antar variabel dependen dengan variabel dependen (Dahlan, 2011).

\section{Populasi dan Sampel}

Adapun populasi dalam penelitian ini adalah Ibu yang memiliki Bayi umur 6-24 bulan sebanyak 184 orang di Puskesmas Caile Kabupaten Bulukumba. Adapun sampel pada penelitian ini adalah Ibu yang memeiliki Bayi umur 6-24 bulan di Puskesmas Caile Kabupaten Bulukumba. Jumlah besaran sampel yang digunakan dalam penelitian ini adalah sebanyak 65 orang dengan berpedoman pada penggunaan rumus slovin (wahyudi, 2017).

\section{Instrument Penelitian}

Instrumen yang digunakan untuk mengukur variabel independen berupa lembar kuesioner dengan fokus pertanyaan mengenai tingkat pengetahuan ibu yang memiliki bayi umur 6-24 bulan dengan 25 item pertanyaan dengan menggunakan model multiple chois (pilihan ganda) dengan pilihan jawaban a, b, c dan d. Sementara itu Instrumen yang digunakan untuk mengukur variabel dependen berupa lembar kuesioner dengan fokus pernyataan mengenai ketepatan waktu pemberian makanan pendampnig ASI dengan 25 item pernyataan dengan menggunakan skala guttman dengan pilihan jawaban ya : 1 , tidak : 0 ,

\section{HASIL PENELITIAN}

Berdasarkan tabel 1 dapat diketahui dari 65 jumlah responden umur ibu yang terbanyak pada kategori umur 30-39 tahun sebanyak 34 orang (52,3\%), sedangkan yang sedikit dengan kategori umur $\geq 40$ tahun sebanyak 5 orang $(7,7 \%)$. Berdasarkan pendidikan ibu yang terbanyak pada kategori SMP sebanyak 26 orang (40,0\%), sedangkan yang sedikit dengan kategori SMA sebanyak 14 orang (21,5\%). Berdasarkan pekerjaan ibu dari 65 jumlah responden yang terbanyak dengan kategori ibu rumah tangga sebanyak 59 orang (90,8\%), 
sedangkan yang sedikit dengan kategori wiraswasta sebanyak 6 orang $(9,2 \%)$. Sedangkan berdasarkan umur anak yang terbanyak pada kategori 1-2 tahun sebanyak 41 orang $(63,1 \%)$, sedangkan yang sedikit dengan kategori 0-1 tahun sebanyak 24 orang $(36,9 \%)$.

Tabel 1. Distribusi Jumlah Responden Berdasarkan Karakteristik responden

\begin{tabular}{|c|c|c|}
\hline Karakteristik Responden & Frekuensi (f) & Persentase $(\%)$ \\
\hline \multicolumn{3}{|l|}{ Umur Ibu } \\
\hline 20-29 Tahun & 26 & 40,0 \\
\hline 30-39 Tahun & 34 & 52,3 \\
\hline$\geq 40$ Tahun & 5 & 7,7 \\
\hline \multicolumn{3}{|l|}{ Pendidikan Ibu } \\
\hline SD & 25 & 38,5 \\
\hline SMP & 26 & 40,0 \\
\hline SMA & 14 & 21,5 \\
\hline \multicolumn{3}{|l|}{ Pekerjaan Ibu } \\
\hline IRT & 59 & 90,8 \\
\hline Wiraswasta & 6 & 9,2 \\
\hline \multicolumn{3}{|l|}{ Umur Anak } \\
\hline 0-1 Tahun & 24 & 36,9 \\
\hline 1-2 Tahun & 41 & 63,1 \\
\hline Jumlah & 65 & 100 \\
\hline
\end{tabular}

Berdasarkan tabel 2 dapat diketahui dari 65 jumlah responden pengetahuan ibu tentang pemberian makanan pendamping ASI yang terbanyak pada kategori baik dan cukup sebanyak 44 orang $(67,7 \%)$, sedangkan yang sedikit dengan kategori baik sebanyak 21 orang $(32,3 \%)$. Ketepatan pemberian makanan pendamping ASI yang terbanyak pada kategori tepat sebanyak 38 orang $(58,5 \%)$, sedangkan yang sedikit dengan kategori tidak tepat sebanyak 27 orang $(41,5 \%)$.

Tabel 2.Distribusi Jumlah Responden Berdasarkan pengetahuan ibu dan ketepatan pemberian pemberian MP-ASI

\begin{tabular}{ccc}
\hline Pengetahuan Ibu & Frekuensi & Persentase (\%) \\
\hline Baik dan Cukup & 44 & 67,7 \\
Kurang & 21 & 32,3 \\
\hline Ketepatan Pemberian MP-ASI & Frekuensi & Persentase (\%) \\
\hline Tepat & 38 & 58,5 \\
Tidak Tepat & 27 & 41,5 \\
\hline Jumlah & $\mathbf{6 5}$ & $\mathbf{1 0 0}$ \\
\hline
\end{tabular}

Berdasarkan tabel 3 diketahui bahwa responden dengan tingkat pengetahuan ibu tentang makanan pendamping ASI kategori baik dan cukup dengan ketepatan pemberian makanan pendamping ASI kategori tepat sebanyak 32 responden (72,7\%). Sedangkan tingkat 
pengetahuan ibu tentang makanan pendamping ASI kategori baik dan cukup dengan ketepatan waktu pemberian makanan pendamping ASI kategori tidak tepat sebanyak 12 responden (27,3\%). Serta tingkat pengetahuan ibu tentang makanan pendamping ASI kategori kurang dengan ketepatan pemberian makanan pendamping ASI kategori tepat sebanyak 6 responden $(28,6 \%)$. Dan yang tingkat pengetahuan ibu tentang makanan pendamping ASI kategori kurang dengan ketepatan pemberian makanan pendamping ASI kategori tidak tepat sebanyak 15 responden $(71,4 \%)$. Hasil analisis dengan menggunakan uji chi-suare diperoleh nilai significancy sebesar 0,001 $(p<0,05)$, maka dapat disimpulkan bahwa "Terdapat Hubungan antara tingkat pengetahuan ibu tentang makanan pendamping ASI dengan ketepatan pemberian makanan pendamping ASI di wilayah kerja puskesmas caile kabupaten bulukumba".

Tabel 3. Analisis Hubungan Antara Tingkat Pengetahuan Ibu Tentang Makanan Pendamping ASI Dengan Ketepatan Pemberian Makanan Pendamping ASI

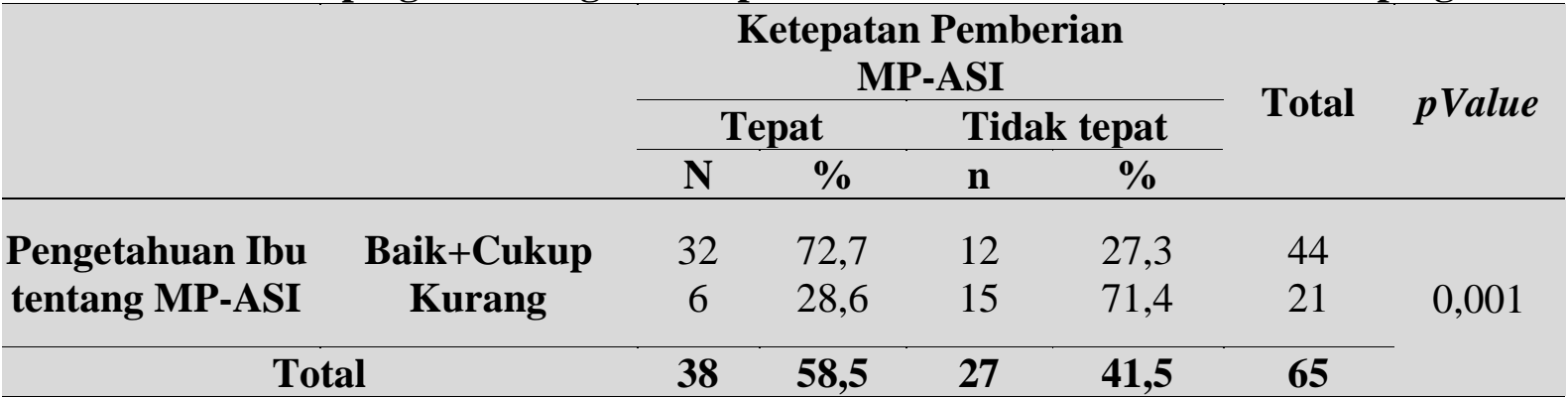

\section{PEMBAHASAN}

a. Tingkat pengetahuan ibu tentang pemberian makanan pendamping ASI

Berdasarkan hasil penelitian dapat diketahui dari 65 jumlah responden pengetahuan ibu tentang pemberian makanan pendamping ASI yang terbanyak pada kategori baik dan cukup sebanyak 44 orang $(67,7 \%)$, sedangkan yang sedikit dengan kategori baik sebanyak 21 orang $(32,3 \%)$.

Berdasarkan penelitian (Andriyani, 2018) tentang hubungan pengetahuan ibu tentang mp-asi terhadap waktu pemberian makanan pendamping ASI pada bayi menunjukkan bahwa dari 78 responden ibu memberikan makanan pendamping ASI kepada bayi pada waktu yang tidak tepat yakni sejumlah 45 orang $(57,7 \%)$. Hasil ini sejalan pula dengan penelitian (Rashid and Nuh, 2017) hubungan antara pengetahuan dan sikap ibu dengan perilaku pemberian makanan pendamping asi pada balita usia 624 bulan di puskesmas padang bulan, menunjukkan bahwa sebagian besar responden mempunyai perilaku baik dalam pemberian makanan pendamping ASI pada bayi yaitu sebanyak 33 orang $(62.3 \%)$. 
Pengetahuan tentang makanan pendamping ASI, sangat penting bagi calon ibu maupun ibu yang sudah mempunyai anak. Pengetahuan mempunyai pengaruh terhadap tindakan atau perilaku seseorang. Pengetahuan adalah segala apa yang diketahui berdasarkan pengalaman yang didapatkan oleh setiap manusia. Sedangkan Notoatmodjo menjelaskan bahwa pengetahuan merupakan hasil tahu dari manusia, yang sekedar menjawab pertanyaan"what", misalnya apa air, apa manusia, apa alam, dan sebagainya. Pengetahuan merupakan respons mental seseorang dalam hubungannya objek tertentu yang disadari sebagai 'ada' atau terjadi dan objek yang disadari memang harus 'ada' sebagaimana adanya (Notoatmodjo dalam (Andriyani, 2018)).

Menurut (Mubarak, 2011) pengetahuan seseorang dipengaruhi oleh beberapa faktor antara lain: pendidikan, pekerjaan, umur, minat, pengalaman, kebudayaan lingkungan sekitar, dan informasi. Sejalan dengan (Rashid and Nuh, 2017) bahwa tingkat pendidikan mempengaruhi cara berfikir dan prilaku, semakin tinggi pendidikan semakin mudah orang tersebut untuk menyerap dan menerima informasi sehingga pengetahuan dan wawasan lebih luas. Selain tingkat pendidikan, lingkungan pekerjaan dapat membuat seseorang memperoleh pengalaman dan pengetahuan, baik secara langsung maupun tidak langsung. Dengan memiliki pengetahuan yang baik maka seseorang akan memberikan perlakuan yang tepat dalam merawat anaknya terutama saat pemberian MP-ASI.

Menurut asumsi peneliti dalam penelitian ini sebagian besar pengetahuan ibu berada dalam kategori cukup, hal ini dipengaruhi pula oleh karakteristik responden seperti tingkat pendidikan responden dimana pendidikan ibu terbanyak pada kategori SMP sebanyak 26 orang (40,0\%), sedangkan yang sedikit dengan kategori SMA sebanyak 14 orang $(21,5 \%)$, sehingga menyimpulkan bahwa semakin tinggi pendidikan seseorang, semakin mudah pula mereka menerima informasi, dan pada akhirnya pengetahuan yang dimilikinya akan semakin banyak, minat sebagai suatu kecenderungan atau keinginan yang tinggi terhadap sesuatu. Pengetahuan yang didapat ibu dari pelayanan puskesmas, karena ibu yang aktif keposyandu dan mengikuti promosi kesehatan diposyandu sehingga meningkatkan pengetahuan ibu tentang makanan pendamping ASI.

Kurangnya pengetahuan ibu tentang makanan pendamping ASI dini dikarenakan bahwa mayoritas responden belum mengetahui secara mendalam tentang makanan pendamping ASI dini. Ibu tahu kapan memberikan makanan pendamping ASI tersebut 
tetapi ibu tetap memberikan makanan pendamping ASI tersebut dengan alasan bayinya tidak kenyang jika di beri ASI saja. Pengetahuan responden rendah hal ini dikarenakan bahwa sebagian besar responden kurang mendapatkan informasi penting mengenai pemberian makanan pendamping ASI.

b. Ketepatan Waktu Pemberian makanan pendamping ASI

Berdasarkan hasil penelitian dapat diketahui dari 65 jumlah responden ketepatan pemberian makanan pendamping ASI yang terbanyak pada kategori tepat sebanyak 38 orang $(58,5 \%)$, sedangkan yang sedikit dengan kategori tidak tepat sebanyak 27 orang (41,5\%). Hasil ini sejalan dengan penelitian (Rohmatika, 2012) hubungan tingkat pengetahuan ibu dengan pemberian makanan pendamping asi bayi umur 6-24 bulan di posyandu karyamulya jetis jaten menunjukkan bahwa pemberian makanan pendamping ASI dengan tingkatan baik sebanyak 26 responden (86,7), tingkatan cukup sebanyak 3 responden $(10,0 \%)$ dan tingkatan kurang sebanyak 1 responden $(3,3 \%)$.

Hasil yang sama dengan penelitian (Andriyani, 2018) tentang hubungan pengetahuan ibu tentang mp-asi terhadap waktu pemberian makanan pendamping ASI pada bayi bahwa pengetahuan ibu tentang makanan pendamping ASI sebagian besar responden berpengetahuan rendah yaitu 42 orang $(53,8 \%)$, dan berpengetahuan tinggi 36 orang $(46,2 \%)$. Didukung pula oleh penelitian (Rashid and Nuh, 2017) tentang hubungan antara pengetahuan dan sikap ibu dengan perilaku pemberian makanan pendamping ASI pada balita usia 6-24 bulan di puskesmas Padang Bulan menunjukkan bahwa pengetahuan responden tergolong baik (52,8\%). Sedangkan berdasarkan penelitian (Tristanti, 2018) pengetahuan ibu tentang makanan pendamping asi bagi bayi umur 6-12 bulan ditinjau dari karakteristik ibu menunjukan bahwa tingkat pengetahuan ibu tentang makanan pendamping ASI sebagian besar responden memiliki pengetahuan yang cukup yaitu sebanyak 13 responden (43,3\%).

Makanan pendamping ASI Merupakan makanan peralihan dari ASI ke makanan keluarga. Pengenalan dan pemberian makanan pendamping ASI harus dilakukan secara bertahap baik bentuk maupun jumlahnya, sesuai dengan kemampuan pencernaan bayi atau anak, pemberian makanan pendamping ASI yang cukup kualitas dan kuantitasnya penting untuk pertumbuhan fisik dan perkembangan kecerdasan anak yang sangat pesat pada periode ini, semakin meningkat umur bayi /anak kebutuhan zat gizi semakin bertambah untuk tumbuh kembang anak (Andriyani, 2018). 
Pemberian ASI Eksklusif yang belum optimal disebabkan oleh pemberian makanan pendamping ASI secara dini. Tingkat pendidikan ibu yang rendah tentang pemberian ASI mengakibatkan ibu lebih sering bayinya diberi susu botol dari pada disusui ibunya, bahkan juga sering bayinya yang baru berusia 1 bulan sudah diberi pisang atau nasi lembut sebagai tambahan ASI (Baharudin, 2014). Makanan pelengkap awal atau makanan pendamping ASI diberikan sebelum usia bulan mengakibatkan dampak negatif jangka panjang dan jangka pendek. Dampak negatif jangka pendek jika bayi diberikan makanan pendamping ASI sebelum usia 6 bulan di antaranya adalah bayi kehilangan nutrisi dari ASI, menurunkan kemampuan isap bayi, memicu diare dan memicu anemia. Sedangkan dampak negatif jangka panjang bila bayi diberikan makanan pendamping ASI sebelum 6 bulan di antaranya adalah obesitas, hipertensi, arterosklerosis, alergi. Tidak tepatnya waktu pemberian makanan pendamping ASI ini disebabkan oleh beberapa alasan salah satunya adalah karena ibu bekerja (Savitri, 2016).

Fakta yang masih sering kita temui di masyarakat adalah masih banyak praktik pemberian makanan pendamping ASI bagi bayi yang berumur kurang dari enam bulan. Makanan pendamping air susu ibu adalah jenis makanan yang dibuat secara khusus baik dari segi tekstur, rasa, bahan menyesuaikan dengan kondisi saluran pencernaan bayi. Pemberian makanan pendamping ASI ini secara bertahap sehingga saluran pencernaan bayi akan beradaptasi dengan jenis makanan yang semula cair, lunak, lumat, padat. Pemberian makanan pendamping ASI diatur secara benar dan tepat, baik secara tahapan waktu maupun kualitasnya. Sehingga tidak menimbulkan risiko gangguan saluran pencernaan dan risiko alergi. Apabila ditinjau dari aspek kesehatan, pemberian makanan pendamping ASI yang terlalu awal yaitu pada bayi berumur kurang dari enam bulan sangat merugikan karena akan menurunkan konsumsi bayi terhadap ASI dan menyebabkan gangguan pencernaan. Gangguan pencernaan yang sering dialami bayi yang diberikan makanan pendamping ASI terlalu awal adalah diare, karena usus bayi belum mampu mencerna makanan secara sempurna (Tristanti, 2018).

Apabila diberikan secara tepat maka sesungguhnya makanan pendamping ASI sangat bermanfaat bagi bayi, antara lain: mampu melengkapi kebutuhan nutrisi yang dibutuhkan bayi karena setelah enam bulan jumlah ASI tidak sebanding dengan kebutuhan bayi, mampu mendukung proses adaptasi bayi untuk menerima berbagai jenis makanan baik tekstur maupun rasa, mampu mendukung kemampuan bayi untuk 
mengunyah dan menelan makanan, dan mampu mendukung adaptasi bayi terhadap makanan yang mengandung sumber energi tinggi. Pemberian makanan pendamping ASI dengan tepat dan benar akan mendukung tumbuh kembang bayi baik kognitif psikomotorik dan menumbuhkan kebiasaan makan yang baik (Rashid and Nuh, 2017).

Menurut asumsi peneliti peranan makanan pendamping ASI sama sekali bukan untuk menggantikan ASI, melainkan hanya untuk melengkapi ASI. Umumnya alasan ibu memberikan makanan pendamping ASI yang tidak tepat sesuai usia bayi adalah karena bayi sering menangis sehingga ibu menganggap bahwa bayinya masih lapar, ibu merasa dengan memberikan makanan tambahan bayi akan sehat serta bayi cepat tumbuh besar. Pengetahuan tentang makanan pendamping ASI seorang ibu juga besar pengaruhnya bagi perubahan sikap dan perilaku di dalam pemilihan bahan makanan yang selanjutnya berpengaruh pada tumbuh kembang dan gizi anak yang bersangkutan. Sebagian besar ibu yang memiliki pengetahuan baik dan cukup seharusnya menerapkan pola pemberian ASI dan makanan pendamping ASI yang baik pada anak, namun dalam penelitian yang dilakukan tentang pola pemberian ASI dan makanan pendamping ASI baik pada anak 24 bulan masih tidak tepat.

Namun masih ada ibu yang belum tahu jika makanan pendamping ASI diberikan terlalu dini dan tidak sesuainya pola asuh yang diberikan justru dapat menggangu sistem pencernaan pada bayi, dan apabila terlambat memberikan juga akan membuat bayi kekurangan gizi serta gangguan tumbuh kembang bayi. Persentasi perilaku makanan pendamping ASI melebihi setengah dari sampel yang diambil, ibu merasa dengan memberikan makanan tambahan bayi akan sehat serta bayi cepat tumbuh besar. Ibu-ibu juga harus tahu bahwa anak-anak yang diberikan makanan pendamping ASI setelah berumur 6 bulan umumnya lebih cerdas dan memiliki daya tahan tubuh lebih kuat, serta mengurangi risiko terkena alergi akibat makanan.

c. Analisa Hubungan Antara Tingkat Pengetahuan Ibu Tentang Makanan Pendamping ASI Dengan Ketepatan Waktu Pemberian Makanan Pendamping ASI

Berdasarkan hasil penelitian diketahui bahwa responden yang tingkat pengetahuan ibu tentang makanan pendamping ASI kategori baik dan cukup dengan ketepatan pemberian makanan pendamping ASI kategori tepat sebanyak 32 responden $(72,7 \%)$. Serta tingkat pengetahuan ibu tentang makanan pendamping ASI kategori kurang dengan ketepatan pemberian makanan pendamping ASI kategori tepat sebanyak 6 responden $(28,6 \%)$. Dan yang tingkat pengetahuan ibu tentang makanan pendamping 
ASI kategori kurang dengan ketepatan pemberian makanan pendamping ASI kategori tidak tepat sebanyak 15 responden $(71,4 \%)$. Hasil analisis dengan menggunakan uji chi-suare diperoleh nilai significancy sebesar 0,001 $(p<0,05)$, maka dapat disimpulkan bahwa "Terdapat Hubungan antara tingkat pengetahuan ibu tentang makanan pendamping ASI dengan ketepatan pemberian makanan pendamping ASI di wilayah kerja puskesmas caile kabupaten bulukumba".

Hasil ini sejalan dengan penelitian (Andriyani, 2018) bahwa dari hasil uji statistik didapatkan hasil $\mathrm{p}$ value 0,001 yang berarti ada pengaruh yang bermakna antara pengetahuan ibu dengan pemberian makanan pendamping ASI dini pada bayi 0-6 bulan. Maka disimpulkan bahwa Ho ditolak dan Ha diterima, hal ini menunjukkan ada hubungan yang signifikan antara pengetahuan ibu terhadap usia awal pemberian makanan pendamping ASI di Puskesmas RI Sidomulyo. Hasil penelitian yang dilakukan oleh (Asri, Mulyono, \& Khasanah, 2020), bahwa tingkat pengetahuan yang tinggi dapat meningkatkan perilaku dan pemahamaman seseorang dalam bertindak.

Hasil ini sejalan pula dengan penelitian (Permatasari, 2019) bahwa hasil penelitian dengan uji chisquare diperoleh nilai $p$ value $0,000<\alpha=0,05$ yang berarti bahwa H1 diterima sehingga terdapat hubungan antara tingkat pengetahuan ibu dengan pemberian makanan pendamping ASI dini. Hasil ini sejalan pula dengan penelitian (Rashid and Nuh, 2017) hasil analisa statistik dengan menggunakan uji chisquare diperoleh nilai $\mathrm{p}$ value $=0,040(\mathrm{p}<0,05)$, artinya ada hubungan secara signifikan antara sikap ibu dengan perilaku pemberian makanan pendamping ASI pada bayi.

Menurut (Tristanti, 2018) MP-ASI tepat diberikan saat usia bayi 6 bulan karena cadangan vitamin dan mineral dalam tubuh bayi yang didapat semasa dalam kandungan mulai menurun, sehingga diperlukan makanan tambahan selain ASI. Makanan pendamping ASI ini diperlukan untuk pertumbuhan dan perkembangan fisik, psikomotor, otak dan kognitif si kecil yang semakin meningkat. Pemberian makanan pendamping ASI yang cukup kualitas dan kuantitasnya penting untuk pertumbuhan fisik dan perkembangan kecerdasan anak semakin meningkat umur bayi zat gizi semakin bertambah untuk tumbuh kembangnya.

Pemberian makanan pendamping ASI terlalu dini pada masyarakat merupakan masalah yang sulit. Meskipun ASI diketahui memiliki banyak keunggulan dari segi gizi, imunitas, ekonomi, kepraktisan, maupun psikologis, tetapi kesadaran ibu-ibu untuk memberikan ASI masih sangat rendah. Adanya praktik 
pemberian makanan pendamping ASI terlalu dini, yaitu pada bayi yang berusia kurang dari 6 bulan, menjadi perhatian yang serius dimana organ-organ pencernaan pada tubuh bayi belum tumbuh sempurna. Hal tersebut disebabkan oleh beberapa alasan, antara lain karena pengetahuan ibu tentang pentingnya ASI masih rendah, kurangnya dukungan keluarga untuk pemberiasn ASI eksklusif, dan banyaknya ibu yang bekerja diluar rumah (Yuliarti, 2014).

Ibu merupakan salah satu faktor yang mempengaruhi pemberian makanan tambahan pada bayi, faktor-faktor tersebut meliputi pengetahuan, kesehatan dan pekerjaan ibu, petugas kesehatan, budaya dan sosial ekonomi. Pengetahuan ibu yang masih kurang terhadap manfaat pemberian ASI eksklusif sangat erat kaitannya dengan pemberian makanan tambahan pada bayi usia 0-6 bulan (Heryanto, 2017). Upaya untuk mengurangi perilaku pemberian makanan pendamping ASI dini dapat dilakukan dengan meningkatkan pengetahuan Ibu dan Keluarga. Kegiatan peningkatan pengetahuan tersebut melalui pemberian penyuluhan atau pendidikan kesehatan agar Ibu dan keluarga lebih memahami bahaya, dampak dan risiko pemberian makanan pendamping ASI dini pada bayi. Peran tenaga kesehatan sebagai pemberi informasi sangat diperlukan untuk gencar mensosialisasikan program ASI eksklusif (Arini, 2017).

Peneliti berasumsi bahwa pemberian makanan pendamping ASI dipengaruhi oleh beberapa faktor antara lain pengetahuan, pekerjaan, pendidikan. Ibu yang memiliki tingkat pengetahuan yang tinggi, akan semakin rendah pemberian makanan pendamping ASI dini pada bayi tersebut. Tingkat pendidikan ibu mencerminkan kemampuan ibu untuk menerima informasi dan pengetahuan yang lebih tentang pemberian makanan pendamping ASI. Akan tetapi tidak menutup kemungkinan ibu yang berpendidikan rendah jika sering mengikuti penyuluhan tentang pemberian makanan pendamping ASI akan menunjukkan pemberian makanan pendamping ASI yang baik. Sebagian besar masyarakat beranggapan bahwa pemberian makanan pendamping ASI secara dini dapat membantu memenuhi kebutuhan nutrisi pada bayi.

Hal ini pula dapat terjadi karena walaupun tingkat pengetahuan ibu baik tetapi dipengaruhi oleh budaya setempat, tradisi keluarga serta anggapan bahwa ASI saja tidak cukup untuk memenuhi kebutuhan bayi. Dari hasil jawaban dari cheklist diketahui bahwa responden mendapatkan informasi mengenai pemberian makanan pendamping ASI dari televisi, koran, majalah, pengalaman dirinya ataupun orang lain. Pengetahuan manusia berhubungan dangan jumlah informasi yang dimiliki seseorang. 
Semakin banyak informasi yang dimiliki maka semakin tinggi pula pengetahuan orang tersebut.

\section{KESIMPULAN DAN SARAN}

Terdapat hubungan antara tingkat pengetahuan ibu tentang makanan pendamping ASI dengan ketepatan waktu pemberian makanan pendamping ASI di wilayah kerja puskesmas Caile Kabupaten Bulukumba. Diharapkan penelitian ini dapat menambah informasi dan masukan bagi petugas kesehatan agar dapat meningkatkan kualitas pelayanan kesehatanyan diberikan dan diharapkan juga akan memberikan manfaat kepada masyarakat dalam hal informasi tentang hubungan antara tingkat pengetahuan ibu tentang makanan pendamping ASI dengan ketepatan waktu pemberian makanan pendamping ASI.

\section{DAFTAR PUSTAKA}

Asri, Mulyono, S., \& Khasanah, U. (2020). Pengaruh Pelatihan Kader Posbindu Terhadap Perilaku Deteksi Dini Hipertensi Pada Usia Dewasa. Jurnal Kesehatan Panrita Husada, 5(1 SE-Articles). https://doi.org/10.37362/jkph.v5i1.315

wahyudi, setyo tri. (2017). Statistika Ekonomi Konsep, Teori dan Penerapan - Setyo Tri Wahyudi - Google Buku.

Ahmad, A., Madanijah, S., Dwiriani, C. M., \& Kolopaking, R. (2019). Pengetahuan, sikap, motivasi ibu, dan praktik pemberian MP-ASI pada anak usia 6-23 bulan: studi formatif di Aceh. Jurnal Gizi Klinik Indonesia, 16(1), 1. https://doi.org/10.22146/ijen.34560

Andriyani Rika. 2018. Hubungan Pengetahuan Ibu Tentang Mp-Asi Terhadap Waktu Pemberian Mp-Asi Pada Bayi. Jurnal Penelitian Kesehatan Suara Forikes Volume 9 Nomor 1, Januari

Anwar, C., \& Ulfa, Z. (2018). Hubungan Pengetahuan dan Status Pekerjaan Ibu dengan Pemberian MP- ASI pada Bayi Usia 7-12 Bulan di Wilayah Kerja Puskesmas Batoh Banda Aceh Tahun 2018 Relationship between Knowledge and Employment Status of Mothers with Giving Breast Milk in Babies 7-12. Journal of Healthcare Technology and Medicine, 4(1), 29-41.

Arikunto. (2006). Pedoman riset praktis untuk profesi perawat. https://books.google.co.id/books?id=uVQetJXybEYC

Arini. 2014. Mengeksplorasi Bagaimana Pengalaman Ibu Bekerja Dalam Keberhasilan Pemberian Makanan Pendamping ASI (MP-ASI) Secara Tepat waktu. Badan Pusat Statistik.

Baharuddin, Afriyani. 2016. Faktor-Faktor Yang Berhubungan Dengan Pemberian Mp-Asi Pada Bayi Usia 0-6 Bulan Di Bpm Nurtila Palembang. jurnal poltekkes

Dian. (2015). MPASI Perdana Cihuy: Pedoman Makanan Pendamping ASI usia 6-12 bulan. https://books.google.co.id/books?id=oJaYCwAAQBAJ\&pg=PP17\&dq=frekuensi+maka 
nan+pendamping+asi+usia+6+bulan\&hl=en \&sa=X\&ved=0ahUKEwiZkJzi5drSAhVFGJ QKHc32A_0Q6AEIRTAH\#v=onepage \&q=frekuensi makanan pendamping asi usia 6 bulan\&f $=$ false

Efendi, N. F. (2008). Pendidikan Dalam Keperawatan - Google Buku (p. Bab 2 pages 15).

Heryanto, Eko. 2017. Faktor-Faktor yang Berhubungandengan Pemberian Makanan Pendamping ASI Dini. Jurnal Ilmu Kesehatan : Stikes Aisyah.

Hidayat, A. A. A. (2017) Metodologi Penelitian Keperawatan dan Kesehatan -. Jakarta: Salemba Medika.

Indrawati, I., \& Anggini, P. Q. (2018). Hubungan Pengetahuan Dan Motivasi Ihn nangan Pemberian Mp-Asi Di Wilayah Kerja Puskesmas Rawasari Kota Jambi. $J_{l}$ Akademika Baiturrahim Jambi, 7(1), 70. https://doi.org/10.36565/jab.v7i1.67

Meta. (2019). Mommyclopedia, fakta tentang MPASI.

Nursalam. (2011). Konsep \& Metode Keperawatan (ed. 2) (p. 97).

Permatasari Dian Indah. 2019. Hubungan Tingkat Pengetahuan Ibu Dengan Pemberian MpAsi Pada Bayi Usia Kurang 6 Bulan Di Wilayahkerjapuskesmas Gemarang. Stikes Bhakti Husada Mulia Madiun

Rashid Mohd, Nuh Muhammad. 2017. Hubungan Antara Pengetahuan dan Sikap Ibu Dengan Perilaku Pemberian Makanan Pendamping ASI Pada Balita Usia 6-24 Bulan di Puskesmas Padang Bulan. Universitas Sumatera Utara

RI DK (2018) Riset kesehatan dasar (RISKESDAS) 2018. Laporan Provinsi Sulawesi Selatan

Rohmatika Dheny . 2012. Hubungan Tingkat Pengetahuan Ibu Dengan Pemberian Makanan Pendamping Asi Bayi Umur 6-24 Bulan Di Posyandu Karyamulya Jetis Jaten. Stikes Kusuma Husada Surakarta

Safitri Salmah. 2016. Determinan Yang Berhubungan Dengan Pemberian Mp-Asi Pada Bayi Usia 0-6 Bulandi Kelurahan Lalombaa Kecamatan Kolaka Kabupaten Kolaka. Fakultas Kesehatan masyarakat Universitas Diponegoro

Sari, A. C., \& Wigunantiningsih, A. (2010). Hubungan Tingkat Pengetahuan Ibu Menyusui Dengan Ketepatan Waktu Pemberian Makanan Pendamping ASI (MP ASI) di Posyandu Bunga Krisan Tulakan Sine Ngawi. Maternal, 3, 73-83.

Sugiharti, R. K. (2017). Hubungan Antara Paritas dan Umur Ibu dengan Pemberian MP-ASI Dini Pada Bayi Umur < 6 BULA. 2008.

Sugiyono, 2014. Metode penelitian kuantitaif, kualitatif dan R\&D. Alfabeta, Bandung.

Tristanti Ika. 2018. Pengetahuan Ibu Tentang Makanan Pendamping Asi Bagi Bayi Umur 612 Bulan Ditinjau Dari Karakteristik Ibu. Jurnal Ilmu Keperawatan dan Kebidanan Vol.9 
No.1 66-74

Wahyudi, setyo tri. (2017). Statistika Ekonomi Konsep, Teori dan Penerapan - Setyo Tri Wahyudi - Google Buku (p. 221 hlm). https://books.google.co.id

Yuliarti, Nurheti. 2014. Keajaiban ASI Makanan Terbaik untuk Kesehatan, Kecerdasan, dan Kelincahan si Kecil. Yogyakarta:Penerbit Andi 